\title{
Oral verrucous carcinoma: a 24-year epidemiological study and case report
}

\author{
Carcinoma verrucoso oral: um estudo epidemiológico de 24 anos e relato de caso \\ Carcinoma verrugoso oral: un estudio epidemiológico de 24 años y reporte de caso \\ Iago Demétrio da SILVA \\ Elen de Souza TOLENTINO \\ Camila CAMARINI \\ Eloise Girondi BERLIN \\ Vanessa Cristina VELTRINI \\ Mariliani Chicarelli da SILVA \\ Fernanda LOBO \\ Dentistry Department, State University of Maringá (UEM), 87080-000 Maringá-PR, Brazil
}

\begin{abstract}
Introduction: Verrucous carcinoma is a non-metastatic variant of squamous cell carcinoma. It was first reported by Ackerman in 1948. It is a verrucous exophytic tumor and, although it is a rare lesion, it mainly affects the oral cavity, with slow growth and can be locally invasive. Objective: To report a case and present an observational and retrospective analysis of medical records containing biopsy data from patients diagnosed with oral verrucous carcinoma (OVC) in an oral diagnostic referral service for a period of 24 years. Material and methods: The following data were collected: age, sex, ethnicity, anatomical location and management. Result: Eight cases of OVC were found, all in Caucasian patients $(n=8,100 \%)$, aged between 57 and 102 years. $62 \%$ of the injuries affected women. The most affected region was the jugal mucosa $(n=4,50 \%)$. In addition, Smoking patients were not found. In all cases, incisional biopsy was performed and referral to the head and neck surgeon. Conclusion: Caucasian women in the sixth and seventh decades of life were the most affected by OVC. The absence of smoking patients corroborates the literature, which reports that cigarettes appear to be unrelated to this injury. The dentist's role is to recognize the disease early, diagnose it and refer it for medical treatment.
\end{abstract}

Descriptors: Epidemiology; Carcinoma, Verrucous; Medical Oncology.

\section{Resumo}

Introdução: O carcinoma verrucoso é uma variante não metastática do carcinoma de células escamosas. Foi primeiramente reportado por Ackerman em 1948. Sendo um tumor verrucoso exofítico, e apesar de ser uma lesão rara, afeta principalmente a cavidade oral, com crescimento lento e pode ser localmente invasivo. Objetivo: Relatar um caso e apresentar uma análise observacional e retrospectiva de prontuários contendo dados de biópsia de pacientes diagnosticados com carcinoma verrucoso oral (CVO) em um serviço de referência em diagnóstico oral por um período de 24 anos. Material e métodos: Foram coletados os seguintes dados: idade, sexo, etnia, localização anatômica e manejo. Resultado: foram encontrados oito casos de CVO, todos em pacientes caucasianos ( $n=8,100 \%$ ), com idades entre 57 e 102 anos. 62\% das lesões afetaram as mulheres. A região mais afetada foi a mucosa jugal $(n=4,50 \%)$. Além disso, pacientes fumantes não foram encontrados. Em todos os casos, foi realizada biópsia incisional e encaminhamento ao cirurgião de cabeça e pescoço. Conclusão: As mulheres caucasianas na sexta e sétima décadas de vida foram as mais afetadas pelo CVO. A ausência de pacientes fumantes corrobora a literatura, que relata que o cigarro parecem não estar relacionados a essa lesão. O papel do dentista é reconhecer a doença precocemente, diagnosticá-la e encaminhá-la para tratamento médico.

Descritores: Epidemiologia; Carcinoma Verrucoso, Oncologia.

\section{Resumen}

Introducción: el carcinoma verrugoso es una variante no metastásica del carcinoma de células escamosas. Fue reportado por primera vez por Ackerman en 1948. Como un tumor verrugoso exofítico, y a pesar de ser una lesión rara, afecta principalmente la cavidad oral, con un crecimiento lento y puede ser localmente invasivo. Objetivo: relatar un caso y presentar un análisis observacional y retrospectivo de registros médicos que contengan datos de biopsias de pacientes diagnosticados con carcinoma verrugoso oral (CVO) en un servicio de referencia en diagnóstico oral durante un período de 24 años. Material y métodos: Se recopilaron los siguientes datos: edad, sexo, etnia, ubicación anatómica y manejo. Resultado: se encontraron ocho casos de CVO, todos en pacientes caucásicos $(n=8,100 \%)$, con edades comprendidas entre 57 y 102 años. El $62 \%$ de las lesiones afectaron a mujeres. La región más afectada fue la mucosa yugal $(n=4,50 \%)$. Además, no se encontraron pacientes fumadores. En todos los casos, se realizó una biopsia incisional y referencia al cirujano de cabeza y cuello. Conclusión: las mujeres caucásicas en la sexta y séptima décadas de la vida fueron las más afectadas por CVO. La ausencia de pacientes que fuman corrobora la literatura, que informa que los cigarrillos no parecen estar relacionados con esta lesión. La función del dentista es reconocer la enfermedad temprano, diagnosticarla y derivarla para recibir tratamiento médico.

Descriptores: Epidemiología; Carcinoma Verrugoso; Oncología Médica.

INTRODUCTION

Verrucous carcinoma (VC) is a nonmetastatic variant of squamous cell carcinoma (SCC) that often presents as an exophytic verrucous tumor. Despite being a rare lesion, the mouth is the most common site of involvement, with the jugal mucosa, tongue, alveolar ridge and lips being the sites usually involved ${ }^{1}$. It presents slow and locally invasive growth, reaching large extensions, causing destruction of adjacent tissues, such as bones and cartilage. Despite this characteristic, metastases are not common ${ }^{2}$.

VC was reported by Lauren V Ackerman in 1948. Since then, known as "Ackermann's tumor" or "verrucous carcinoma of Ackermann" 3 . Surgery has been suggested as the first treatment option, and radiotherapy is controversial because radiation can induce an anaplasic transformation ${ }^{4}$.

The aim of this work is to report a case and present an observational and retrospective analysis of medical records containing biopsy data from patients diagnosed with oral verrucous carcinoma (OVC) in an oral diagnostic referral service for a period of 24 years. 


\section{MATERAIL AND METHOD}

After ethical approval (CAE 17835819.1.0000.0104), this observational and retrospective study was conducted in accordance with the Declaration of Helsinki guidelines and according to STROBE (Strengthening the Reporting of Observational Studies in Epidemiology) initiative. Data from medical records of patients referred to the Service of Oral Diagnosis of the Maringa State University (LEBU/UEM) from 1995 to 2019 were collected. Demographic (age, sex, ethnicity) and clinical data (anatomical location and management) of patients with OVC were recorded. Only patients with fully completed records and confirmed OVC microscopic diagnosis were included.

The data were evaluated through frequency and distribution tables, using the SPSS (Statistical Package for Social Sciences) software version 22.0 (SPSS Inc., Chicago, IL, USA).

RESULTS

\section{- Demographic data}

Of the 274 records, 8 patients (2, 9\%) presented OVC; 3 (38\%) men and 5 (62\%) women, with a with a sex ratio of 1:1.6 (Figure 1). Only Caucasians were affected $(n=8 ; 100 \%)$. The age of the individuals with OVC ranged from 57 to 102 years (mean 77.6 years) (Table 1).

Table 1. Characteristics of OVC

\begin{tabular}{l|l|l|l|l|l}
\hline Patient & Sex & $\begin{array}{l}\text { Age } \\
\text { (years) }\end{array}$ & Ethnicity & Smoker & Location \\
\hline 01 & Woman & $\mathbf{1 0 2}$ & Caucasian & No & Upper alveolar ridge \\
\hline 02 & Woman & 74 & Caucasian & No & Left jugal mucosa \\
\hline 03 & Woman & 79 & Caucasian & No & Left jugal mucosa \\
\hline 04 & Woman & 75 & Caucasian & No & Hard palate \\
\hline 05 & Woman & 87 & Caucasian & No & Right jugal mucosa \\
\hline 06 & Man & 75 & Caucasian & No & Left jugal mucosa \\
\hline 07 & Man & 72 & Caucasian & No & Left tongue border \\
\hline 08 & Man & 57 & Caucasian & No & Lower lip mucosa \\
\hline
\end{tabular}

\section{- Clinical characteristics of OVC}

The jugal mucosa $(n=4 ; 50 \%)$ was the predominant location. Other affected regions were hard palate $(n=12.5 \%)$, tongue border $(n=\mid 12.5 \%)$, lower lip mucosa $(n=\mid 12.5 \%)$ and upper alveolar ridge ( $n=1$ 12.5\%) (Table 1). Three patients $(37.5 \%)$ were clinically diagnosed with previous verrucous leukoplakia.

The mean reported time of evolution of the lesions was 22, 37 months, equivalent to 01 year and 10 months, with a minimum of 02 months and a maximum of 120 months. The lesion size ranged from 01 to $07 \mathrm{~cm}$, with a mean of $04 \mathrm{~cm}$. Smoking patients were not found. In all cases, incisional biopsy was performed and referral to the head and neck surgeon.

\section{CLINICAL CASE}

A 87-year-old-woman, leukoderma sought assistance in the LEBU-UEM project.
Following the clinical examination, it was possible to observe the presence of an asymptomatic white verrucous plaque in the maxillary tuber mucosa extending to the right jugal mucosa, with a one-year evolution time. From the clinical characteristics of the lesion, the diagnostic hypotheses of proliferative verrucous leukoplakia and verrucous carcinoma were raised. (Figure 1).

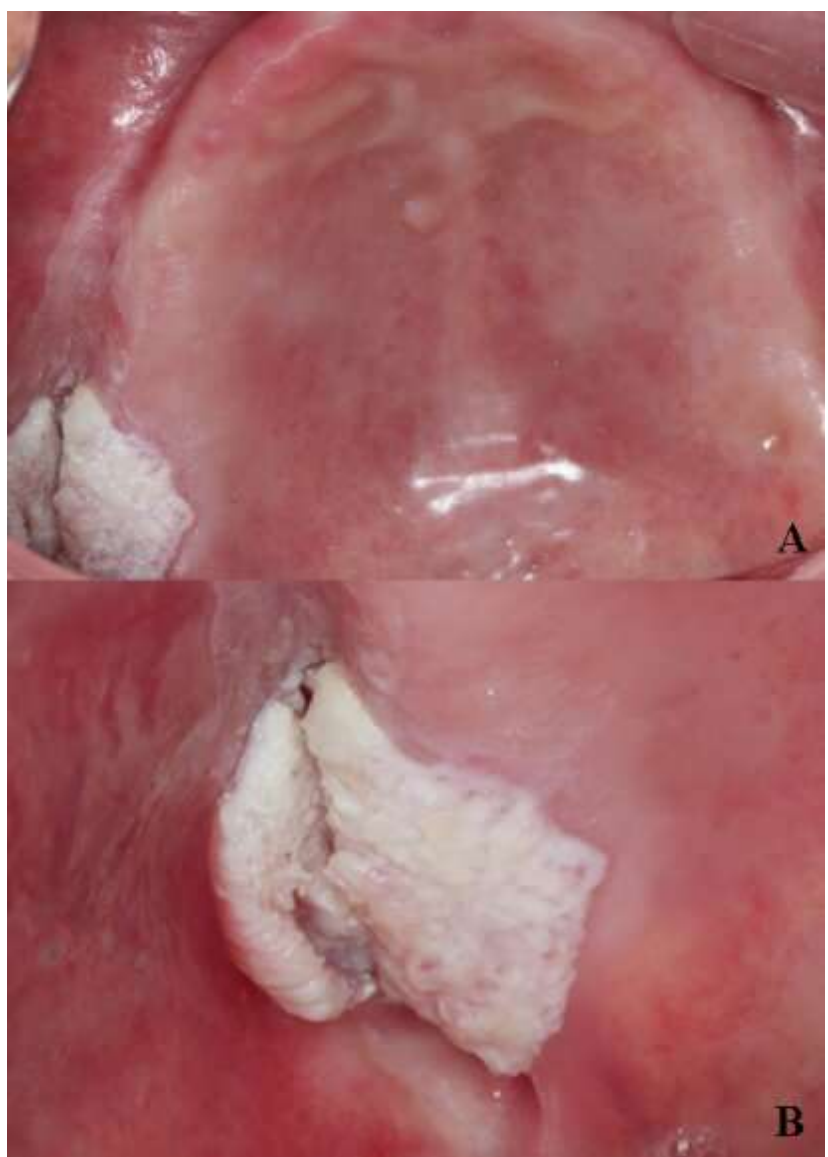

Figure 1: Clinical aspect of verrucous carcinoma (A and B), with approximately $2 \mathrm{~cm}$.

With local anesthesia, an incisional biopsy was performed removing two fragments, both with approximately $7 \mathrm{~mm}$ that were placed in a container with formaldehyde and sent to histopathological analysis. (Figure 2).

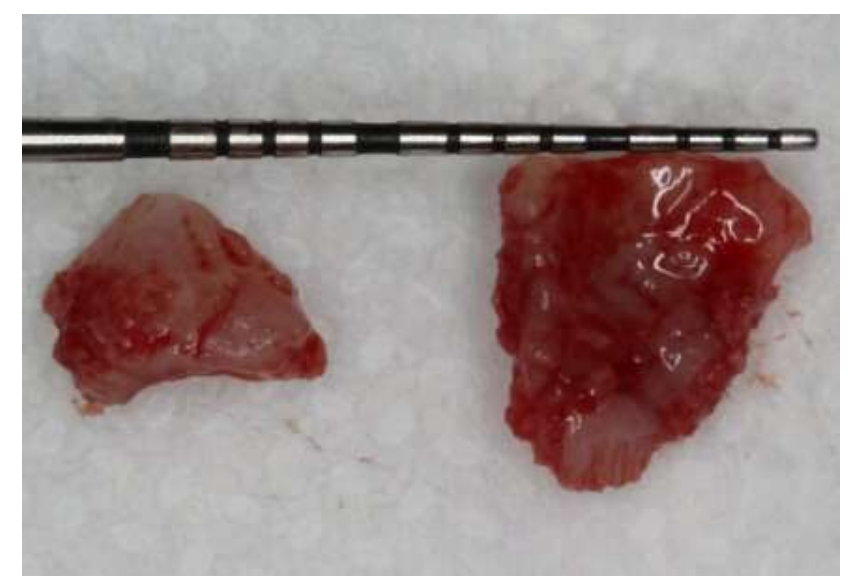

Figure 2. Removed fragments after incisional biopsy.

The histopathological examination 
showed a marked epithelial hyperplasia with an irregular, papillary surface, with formation of keratin plugs (Figure $3 \mathrm{~A}$ ), and in another increase, showed bulbous epithelial ridges without significant dysplasia (Figure 3B). Confirming the diagnosis of VC. The patient was referred to an oncologist that performed a total removal of the lesion, not applying radiotherapy or chemotherapy after the surgery. The patient remains in follow-up showing normality.

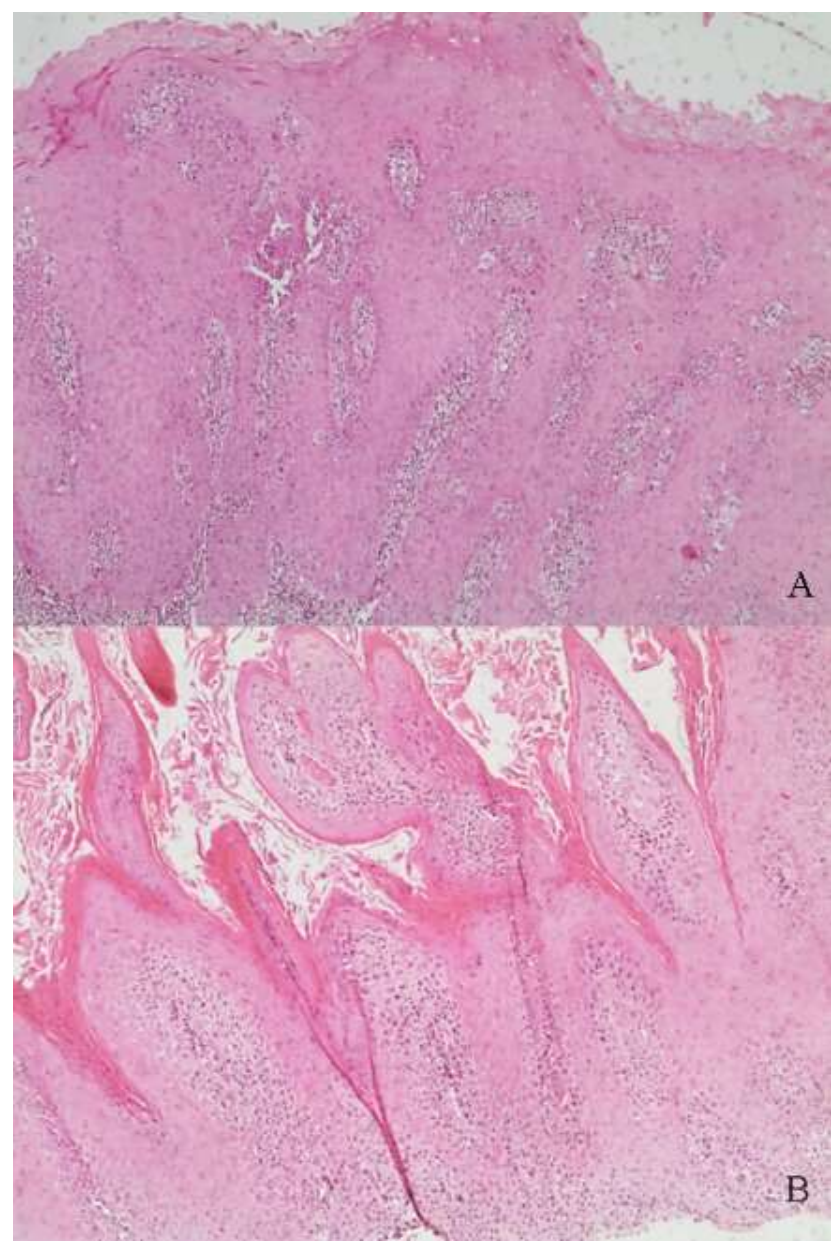

Figure 3. Histopathological examination confirming the diagnosis of VC. (A) Showing epithelial hyperplasia and keratin plugs. (B) Ridges without significant dysplasia.

DISCUSSION

OVC is a rare, and the pathogenesis is still debatable, but it is believed to be associated with human papillomavirus (HPV), and addiction to chewable tobacco and betel nut ${ }^{4}$.

Walvekar et al. ${ }^{5}$, Huang et al. ${ }^{6}$, who studied Asian populations, found a higher incidence of OVC in men, with $77.4 \%$ and $94.9 \%$, respectively. The culture of consuming betel nuts and chewing tobacco seems to explain these indicators. On the other hand, Candau-Alvarez et al. ${ }^{1}$, in a Spanish population, found the highest incidence (57\%) in women. It is known that chewing habits are not common in Caucasians. Likewise, we found that women were most affected (62\%) and no patient reported using tobacco.
Neville et al. ${ }^{7}$ presents that in addition to the oral mucosa, VC has been identified in several extraoral sites, including the laryngeal, vulvovaginal, penile, anorectal, sinonasal and esophageal, as well as on the skin of the breast, armpit, ear canal and soles of the feet. Tumors in different anatomical sites of the mouth are not related to tobacco use.

Walvekar et al. ${ }^{5}$, Huang et al. ${ }^{6}$, Rekha e Angadi ${ }^{8}$ agree that OVC mainly affects patients between 40 and 60 years old. Candau-Alvarez et al. ${ }^{1}$ found an average age of 69.14 years. We found an average of 77.6 years, corroborating the literature. Rekha e Angadi ${ }^{8}$ showed a higher frequency in patients in the fifth decade of life. In addition, the authors found a higher prevalence of lesions in the mandible.

Oliveira et al. ${ }^{9}$ and Zhu et al. ${ }^{10}$ reported greater involvement in the lower lip, while Bagan et al. ${ }^{11}$ and Gandolfo et al. ${ }^{12}$ found that alveolar ridge and gingiva were the most affected. In our study, jugal mucosa represented $50 \%$ of the cases. Several studies Alvarez-Candau et al. ${ }^{1}$, Walvekar et al. ${ }^{5}$, Oliveira et al. ${ }^{9}$, Bagan et al. ${ }^{13}$, Liu et al. ${ }^{14}$ point to the presence of previous leukoplakia, with the OVC appearing late. In our study, three patients (37.5\%) were clinically diagnosed with previous verrucous leukoplakia.

The evolution of a leukoplakia can be explained by the system adopted by Hansen et al. ${ }^{15}$ that takes account of clinical and microscopic aspects. Early stage lesions, clinically present homogeneous or nonhomogeneous leukoplakias, diagnosed as hyperkeratosis. In the intermediate or premalignant stage, present as lesions with a verrucous aspect, diagnosed as verrucous leukoplakia or verrucous hyperplasia. In the late or malignant stage, present as an exophytic verrucous mass with a larger diameter, then diagnosed as verrucous carcinoma.

Microscopically VC presents large associated epithelial streaks over the connective tissue, large keratin production and a papillary or verrucous surface. Parakeratin usually fills in numerous slits and crypts (plugs) between the projections of the surface. Neoplastic epithelial cells present a normal pattern of maturation without a significant degree of cell atypia and the connective tissue presents an intense chronic inflammatory infiltrate ${ }^{7}$.

The differential diagnosis of VC includes the SCC, verruca vulgaris, amelanotic melanoma, histoplasmosis, secondary syphilis, Darier's disease, white sponge nevus and lupus erythematosus ${ }^{16}$.

Treatment modalities for OVC include surgical excision, chemotherapy, cryosurgery, 
intralesional or iontophoretic methods, systemic retinoid therapy and radiotherapy ${ }^{17}$.

Neville et al. ${ }^{7}$ points that the treatment of choice is surgical excision, and if cervical lymphadenomegaly is clinically evident, selective neck dissection can be performed, although most cases may experience reactive lymphadenopathy instead of metastasis. Approximately $90 \%$ of patients are disease-free after surgery. Radiotherapy is an alternative form of primary treatment, with worse local control, being considered less effective than surgery. In addition, it has been unpopular due reports of development of poorly differentiated anaplastic carcinoma after treatment.

CONCLUSION

Because OVC are malignant lesions, knowledge of their epidemiology and characteristics is important for a correct management. We found a prevalence of $0,029 \%$ and Caucasian women over 60 were most affected. The absence of smoking patients corroborates the literature, which reports which cigarette seems to be unrelated to this injury. The role of the dental practioner is to recognize the disease early, make the correct diagnosis and referral for medical treatment.

\section{REFERENCES}

1. Candau-Alvarez A, Dean-Ferrer A, AlamillosGranados F, Heredero-Jung S, Garcia-Garcia $B$, Ruiz-Masera et al. Verrucous carcinoma of the oral mucosa: An epidemiological and followup study of patients treated with surgery in 5 last years. Med Oral Patol Oral Cir Bucal. 2014; 19(5):e506-11.

2. Koch BB, Trask DK, Hoffman HT, Karnell LH, Robinson RA, Zhen W et al. National survey of head and neck verrucous carcinoma. Cancer. 2001;92(1):110-20.

3. Ackerman LV. Verrucous carcinoma of the oral cavity. Surgery. 1948;23:670-78.

Mohammadi K, Mohiyuddin SMA, Harshitha N, Suresh TN, Prasad CSBR, Sagayaraj $A$ et al. Outcome of treatment in verrucous carcinoma of oral cavity: a tertiary rural hospital experience. Indian J Otolaryngol Head Neck Surg. 2020. s12070-019-01782-z

4. Walvekar RR, Chaukar DA, Deshpande MS, Pai OS, Chaturvedi $P$, Kakade $A$, et al. Verrucous carcinoma of the oral cavity: A clinical and pathological study of 101 cases. Oral Oncol. 2009;45(1):47-51.

5. Huang TT, Hsu LP, Hsu YH, Chen PR. Surgical Outcome in Patients with Oral Verrucous Carcinoma: Long-Term Follow-Up in an Endemic Betel Quid Chewing Area. ORL J Otorhinolaryngol Relat Spec. 2009;71(6): 323-28.
6. Neville BW, Damm DD, Allen CM, Chi AC. Patologia Oral e Maxilofacial. 4.ed. Rio de Janeiro: Elsevier; 2016.

7. Rekha KP, Angadi PV. Verrucous carcinoma of the oral cavity: a clinico-pathologic appraisal of 133 cases in Indians. Oral Maxillofac Surg. 2010;14(4):211-18.

8. Oliveira DT, de Moraes RV, Filho JFF, Neto JF, Landman G, Kowalski LP. Oral verrucous carcinoma: a retrospective study in São Paulo Region, Brazil. Clin Oral Investig. 2006;10(3): 205-9.

9. Zhu LK, Ding YW, Liu W, Zhou YM, Shi LJ, Zhou ZT. A clinicopathological study on verrucous hyperplasia and verrucous carcinoma of the oral mucosa. J Oral Pathol Med. 2011;41(2):131-35.

10. Bagan JV, Jiménez-Soriano Y, Diaz-Fernandez J M, Murillo-Cortés J, Sanchis-Bielsa JM, Poveda-Roda, et al. Malignant transformation of proliferative verrucous leukoplakia to oral squamous cell carcinoma: A series of 55 cases. Oral Oncol. 2011;47(8):732-35.

11. Gandolfo S, Castellani R, Pentenero M. Proliferative Verrucous Leukoplakia: A Potentially Malignant Disorder Involving Periodontal Sites. J Periodontol. 2009;80(2): 274-81.

12. Bagan J, Scully C, Jimenez $Y$, Martorell $M$. Proliferative verrucous leukoplakia: a concise update. Oral Dis. 2010:16(4):328-32.

13. Liu W, Shen XM, Liu Y, Li J, Zhou ZT, et al. Malignant transformation of oral verrucous leukoplakia: a clinicopathologic study of 53 cases. J Oral Pathol Med. 2011;40(4):312-16.

14. Hansen LS, Olson JA, Silverman S. Proliferative verrucous leukoplakia. Oral Surg Oral Med Oral Pathol. 1985;60(3):285-98.

15. Warshaw EM, Templeton SF, Washington CV. Verrucous carcinoma occurring in a lesion of oral lichen planus. Cutis. 2000;65:219-22.

16. Stephen JM, Vincent RH. Plastic surgery. 6.ed. Philadelphia: Elsevier; 2006.

\section{CONFLICTS OF INTERESTS}

The authors declare no conflicts of interests.

CORRESPONDING AUTHOR

\section{lago Demétrio da Silva}

1550, Mandacaru Avenue,

87080-000 Maringá - PR, Brazil

Email: lagodemetrio95@gmail.com 